\title{
Assessment of Ti6Al4V alloy fatigue properties based on specimens produced by DMLS technology
}

\author{
Karolina Karolewska ${ }^{1 *}$ \\ ${ }^{1}$ Bydgoszcz University of Science and Technology, Faculty of Mechanical Engineering, Al. Prof. S. \\ Kaliskiego 7, 85-796 Bydgoszcz, Poland
}

\begin{abstract}
The Ti6Al4V alloy produced by additive methods is the most studied material, which can be attributed to its wide application and the resulting need for a thorough understanding of this material and its behavior under static and fatigue loads. For this reason, the paper presents the results of tests of the Ti6Al4V alloy produced by the additive method and in the standard smelting process. The publication contains the results of the alloy tests under static and variable loads based on strain control.
\end{abstract}

\section{Introduction}

The main advantage of additive technologies is the possibility of making complex structural elements, the production of which using conventional methods (e.g. machining, casting) is difficult or impossible to implement. One of the most important aspects of additive technologies is the ability to produce a material with a microstructure composed of a wide range of crystallographic phases [1]. The cost of producing a single structural element with a complex structure by the additive method is lower compared to standard manufacturing techniques.

The use of additive technologies allows to significantly shorten the time of creating finished products and therefore becomes more and more competitive in relation to conventional metallurgical processes, such as casting or forging. Standard manufacturing techniques require the operation of the removal of auxiliary material to obtain a finished product. This means that a large amount of material is required to make a construction element, often much more than the quantity the element is made of. Additive technology produces much less waste, and thus it translates into economic savings [2]. In fact, additive manufacturing does not require the use of tools to obtain ready-made components, and therefore is not affected by the costs associated with: tool replacement for wear, removal of lubricants from cutting tools. Therefore, additive manufacturing is convenient when making components from highhardness materials. This translates into the lack of tool wear, the production of waste is limited, and there are no secondary processes, thanks to which the production time is shortened, and thus costs are reduced $[3,4]$.

* Corresponding author: karolina.karolewska@pbs.edu.pl 
In addition, additive technologies offer advantages in terms of product customization and the creation of free-form objects. In each additive technology, the process of component production is preceded by the creation of a three-dimensional computer model, which allows for quick changes and better adjustment of the element without the need to make a detail [5]. It is extremely useful in the field of dental prosthetics and medicine. Such a method of modeling and manufacturing elements allows to reduce their mass, thanks to which additive methods are more and more often used in the aviation industry (i.e. production of selected structural elements of engines), the tool industry (i.e. production of molding inserts in molds for polymer processing) or sports motor vehicles (i.e. the production of selected vehicle components) [6]. Additive technologies are often used in medicine to produce various types of implants. Elements that replace fragments of the human body in most cases are characterized by very complex geometry and structure. Due to the high dependence between additive technology and $3 \mathrm{D}$ computer modeling, it is easier and more accurate to adjust the implant to the patient's body. One of the most commonly used materials in medicine are biodegradable plastics, i.e. polylactide, polycaprolactone and polycaprolactonehydroxyapatite composite [7]. Implants made of such materials are implanted as a replacement for soft tissues or cartilage for a short period of time, after which they dissolve in the patient's body.

In the case of bone implants, which must withstand greater loads and fulfill their function for the rest of the patient's life, they are made of metallic materials. The medical industry in the production of implants that replace skeletal defects requires high strength, plasticity and hardness of the material. The implant should take the load and thus relieve the damaged bone, therefore it is necessary that the material from which it will be made has greater stiffness and a higher Young's modulus than the bone. An equally important aspect is the possibility of creating a porous structure of the implant, which is a scaffold and allows for the reconstruction of natural tissue. The most popular material in this field is the titanium alloy Ti6Al4V, which has gained its application thanks to its biocompatibility with human tissue, as well as low weight and corrosion resistance [8].

Additively manufactured components are believed to have great potential in aerospace applications. The performance of aerospace components can be improved with new and innovative design solutions that are now possible with additive technologies. The lightweight structure is a good example of a performance improvement that would be attractive to the aerospace industry. The lower weight of the aircraft could contribute to increasing the flight range, increasing the payload and reducing fuel consumption [9]. The Ti6Al4V alloy produced by additive methods is the most frequently studied material, which can be attributed to its wide application and the resulting need for a thorough understanding of this material and its behavior under static and fatigue loads [10].

\section{Experimental research}

\subsection{Research specimens}

The test object under static and variable loads were samples made in accordance with the PN-74 / H-04327 standard entitled "Testing metals for fatigue. Axial tension-compression test with a constant cycle of external loads "[11]. The geometrical dimensions of the samples are presented in Figure 1. A sample with a round cross-section was adopted for the tests due to the uniform distribution of loads in it during the tensile test. One of the factors influencing the even distribution of the load is the repeatable method of mounting in the holders of the testing machine, which ensures that the axis of symmetry of the sample coincides with the axis of symmetry of the holders of the machine. Uniform load on the cross-section allows to 
assume that the structural changes in the material in the $x-z$ plane and in the $y-z$ plane will be the same. This will allow for the implementation of structural research only for one of the above-mentioned planes. The test samples were made of Ti6Al4V material by two methods: by turning a drawn bar with a diameter of $12 \mathrm{~mm}$ (PC sample) and by using additive technology - Direct Metal Laser Sintering (DMLS sample). Then, heat treatment was applied in order to obtain a stable material structure, which consisted in annealing the samples at the temperature of $840^{\circ} \mathrm{C}$ for 1 hour, and then cooling it to ambient temperature.

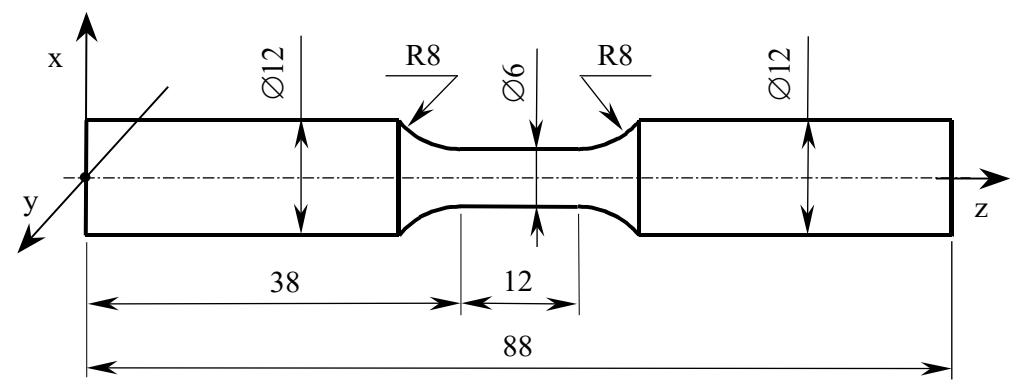

Fig.1. Geometric features of a sample for testing under static and variable loads according to the standard [11].

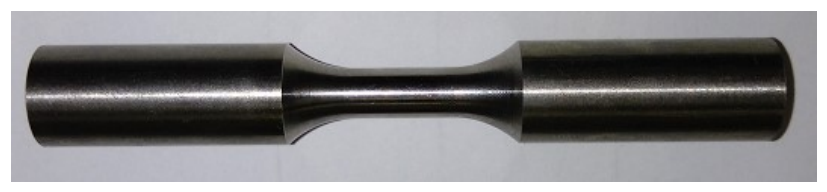

Fig.2. Physical form of test specimens under static and variable loads made of a drawn bar.

The second series of samples was made of Ti6Al4V titanium alloy with the use of additive technology based on selective laser sintering, i.e. DMLS. The properties of the printing powder given in the manufacturer's catalog card are presented in Table 1 . The physical form of the sample for static and fatigue tests made with the DMLS additive technology is shown in Figure 3.

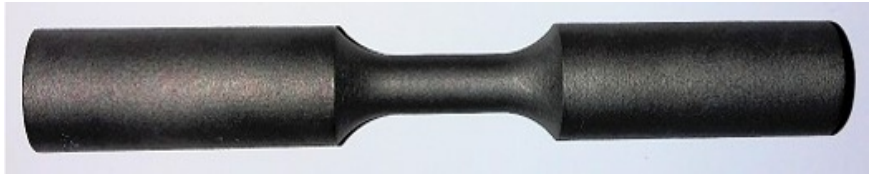

Fig 3. Physical form of samples for testing under static and variable loads, made with the DMLS technology.

Table 1. Mechanical properties of TI6Al4V powder according to the percentage by EOS.

\begin{tabular}{|c|c|c|c|}
\hline \multicolumn{4}{|c|}{ Mechanical properties of Ti6A14V material } \\
\hline 1 & 2 & 3 & 4 \\
\hline $\mathrm{S}_{\mathrm{u}}$ & $\mathrm{Sy}_{0.2}$ & $\mathrm{~A}$ & $\mathrm{E}$ \\
\hline $\mathrm{MPa}$ & $\mathrm{MPa}$ & $\%$ & $\mathrm{MPa}$ \\
\hline 1150 & 1030 & 11 & 110000 \\
\hline
\end{tabular}




\subsection{Research stand}

In order to determine the mechanical properties of the Ti6Al4V material, a static tensile test was carried out, which is the basic method of strength testing of construction materials. This test has become the most popular due to the ease of carrying out, as well as the possibility of observing and recording the stretching process from the beginning of the sample load until its destruction, and the possibility of determining a number of indicators characterizing various material properties.

a)

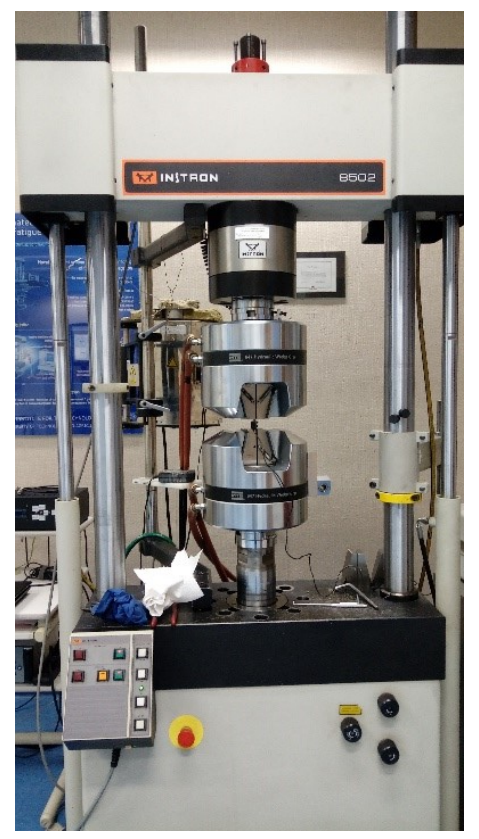

b)

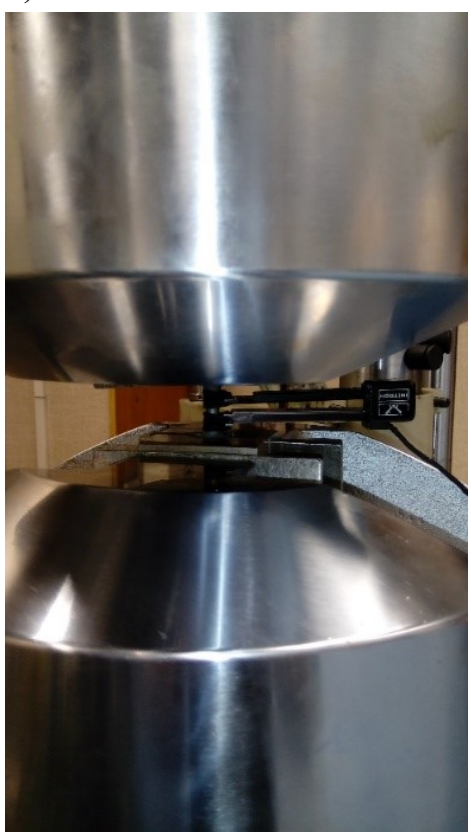

Fig. 4. Test stand for static and fatigue tests: a) view of the Instron 8502 testing machine, b) view of the test sample in the machine holders with the extensometer installed.

As part of the tests, a static tensile test was carried out in accordance with the recommendations of PN-EN ISO 6892-1: 2016, entitled "Metals. Tensile test. Part 1: Test method at room temperature" [12] on the INSTRON 8502 testing machine (Fig.4). The controlling parameter during the tests was the displacement of the machine piston, amounting to $0.05 \mathrm{~mm} / \mathrm{s}$. During the tests, the loading force and deformation were recorded. The tests were carried out with the use of an INSTRON 2620-601 extensometer (Fig. 4b) with a measuring base of $10 \mathrm{~mm}$ and a measuring range of $1 \mathrm{~mm}$. The tests were carried out under the conditions of constant amplitude variable loads $\mathrm{R}=-1$. The control parameter of the test was the deformation value $\varepsilon$ in the range of $0.5 \div 0.8 \%$.

\subsection{Tests under static and variable loads}

Based on the graphs, the mechanical properties of the Ti6Al4V titanium alloy were determined: material tensile strength $S_{\mathrm{u}}$, yield strength $\mathrm{S}_{\mathrm{y} 0.2}$, longitudinal elasticity modulus (Young's modulus) E, elongation A, contraction Z. Table 2 summarizes the average value of selected strength parameters. 
Table 2. Average values of static mechanical properties under tensile loads.

\begin{tabular}{|c|c|c|c|c|c|}
\hline \multirow{2}{*}{ Metoda wytwarzania materiału } & \multicolumn{5}{|c|}{ Mechanical properties of Ti6A14V material } \\
\cline { 2 - 6 } & $\mathrm{S}_{\mathrm{y} 0,2}$ & $\mathrm{~S}_{\mathrm{u}}$ & $\mathrm{E}$ & $\mathrm{A}$ & $\mathrm{Z}$ \\
\cline { 2 - 6 } & $\mathrm{MPa}$ & $\mathrm{MPa}$ & $\mathrm{MPa}$ & $\%$ & $\%$ \\
\hline 1 & 2 & 3 & 4 & 5 & 6 \\
\hline DMLS & 1052 & 1127 & 114510 & 15.5 & 17.3 \\
\hline Drawn bar & 947 & 1010 & 113060 & 29.7 & 38.1 \\
\hline
\end{tabular}

The tests carried out under tensile load conditions show that DMLS samples are characterized by a higher tensile strength $\mathrm{Rm}$ and a proof stress $\mathrm{S}_{\mathrm{y} 0.2}$ compared to samples made of a drawn bar. For both technologies of sample production, similar values of Young's modulus were obtained. On the other hand, the values of elongation $\mathrm{A}$ and narrowing $\mathrm{Z}$ for a sample made of a drawn bar are almost twice as high as those obtained for the DMLS sample. The strength results are influenced by the sample manufacturing technology. The DMLS method of producing samples can be compared to the process of welding a material. The layers of metal powder sintered in the DMLS process form a kind of weld. As in the case of the weld, the element produced in the sintering process is characterized by higher strength properties with slightly lower ductility and elongation compared to the parent material.

Figure 5 shows selected hysteresis loops for $0.1 \mathrm{~N}, 0.5 \mathrm{~N}$ and $0.9 \mathrm{~N}$ of the number of cycles for four strain values. The presented comparisons show that the material until it reaches 0.1 $\mathrm{N}$ undergoes cyclical softening. On the other hand, after reaching $0.1 \mathrm{~N}$, the strain-stress loop becomes stabilized.

a)

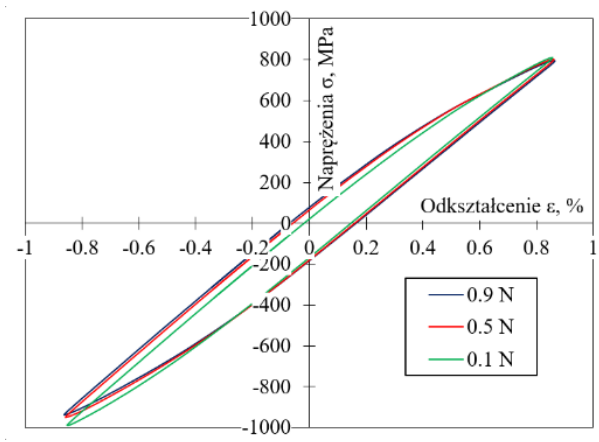

c)

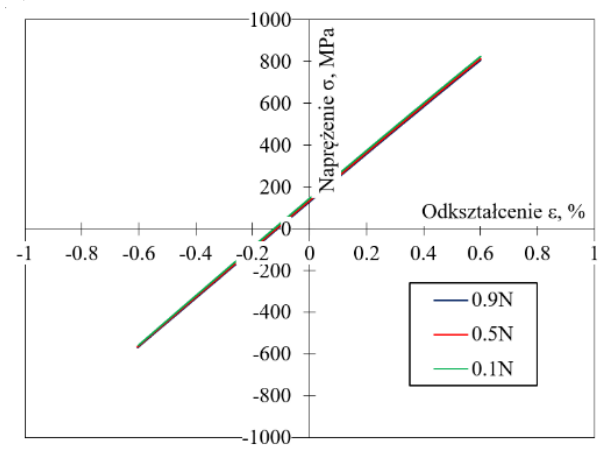

b)

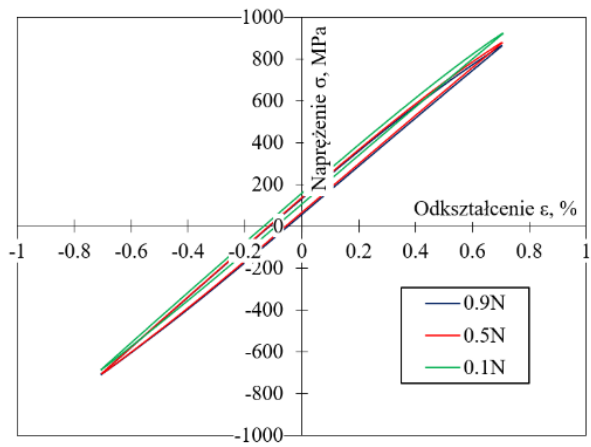

d)

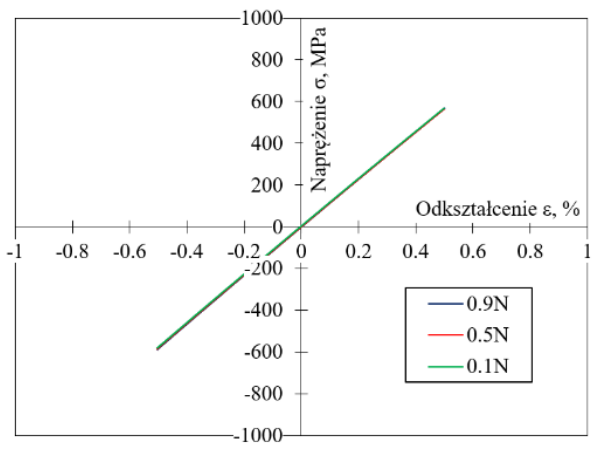


Fig. 5. Selected hysteresis loops for deformation control at the level of: a) $0.8 \%, b) 0.7 \%$, c) $0.6 \%$, d) $0.5 \%$.

\subsection{SEM research}

In addition to the tests under static and variable loads, photos were also taken using a scanning electron microscope (SEM). SEM is used due to the large depth of field, it is used to perform fractographic studies, i.e. the study of the topography of breakthroughs. SEM wear tests consist in the observation of the fracture surfaces, which arise as a result of stresses leading to the separation of the material. Due to the fact that cracks are usually initiated in the weakest zones of the sample, at the fracture various details of the material structure may be shown, i.e. separation of foreign phases, material defects (porosity, voids, microcracks).

The structural assessment was performed on the fractures of the samples made of a drawn bar (PC samples) and those produced by the DMLS method (DMLS samples) obtained after a static tensile test and obtained as a result of fatigue tests. An electron microscope, shown in Figure 6, was used to take the structural images.

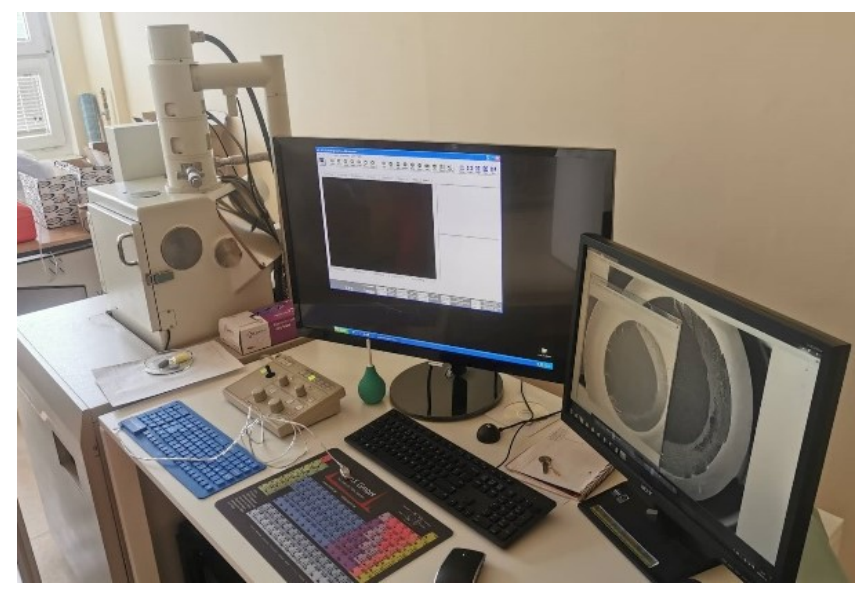

Fig.6. Stand for testing sample topography - SEM.

a)

b) 

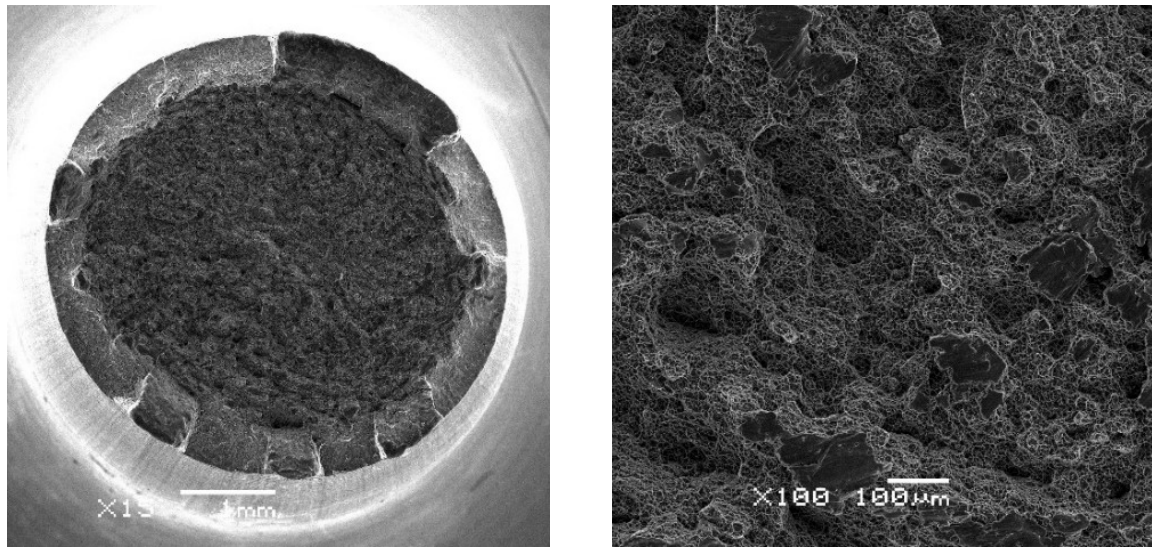

c)

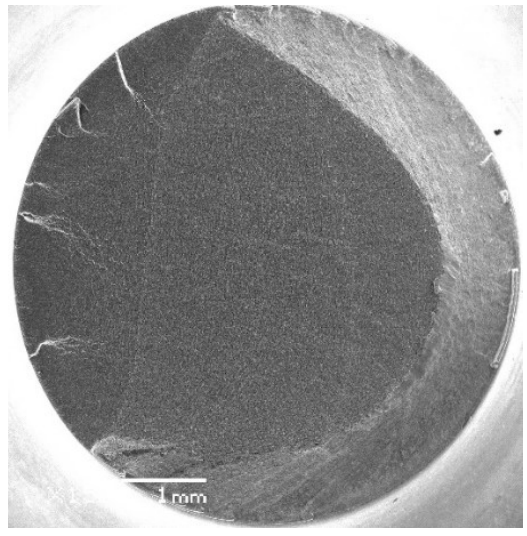

d)

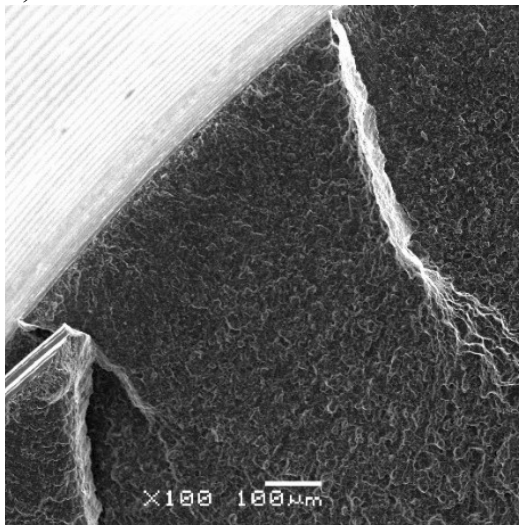

Fig. 7. Structure of Ti6Al4V material from a drawn bar (DB Specimen): fracture created after a static tensile test: a) zoom x15, b) zoom x100, fracture created after fatigue tests: c) zoom x15, d) zoom x100.

a)

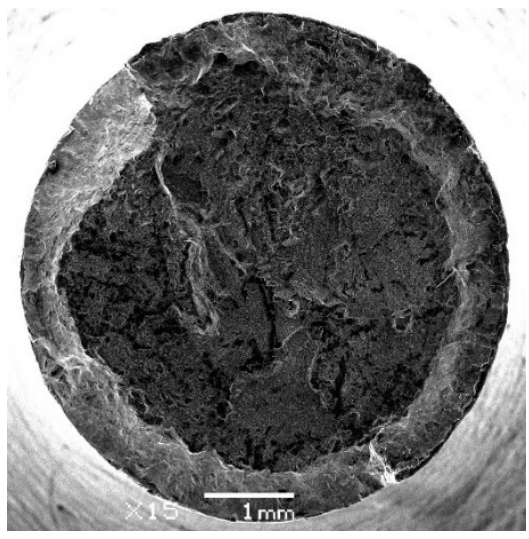

b)

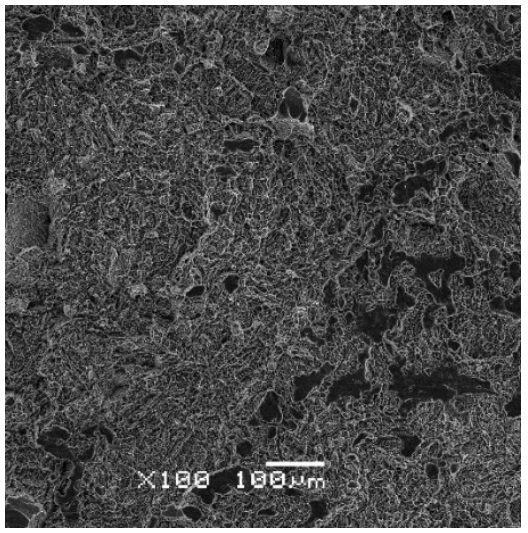


c)

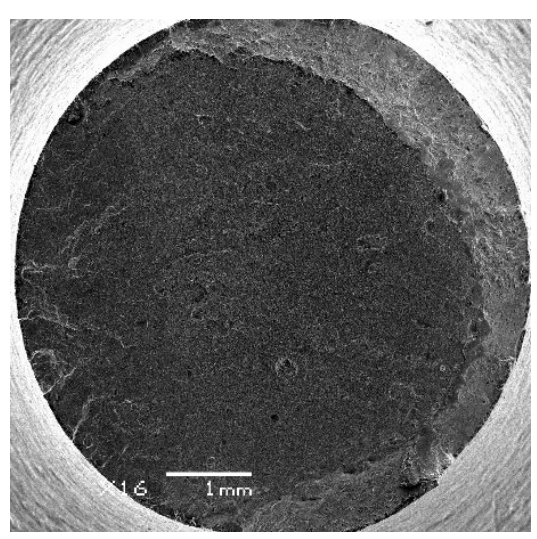

d)

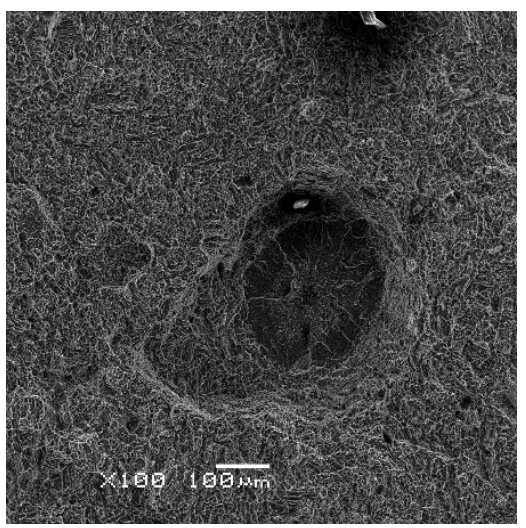

Fig. 8. Structure of the Ti6Al4V material (DMLS sample): fracture created after a static tensile test: a) zoom $\times 15$, b) zoom $\times 100$, fracture created after fatigue tests: c) zoom x15, d) zoom x100

Figure 7 shows the fracture structures for the DB sample. Figures $7 \mathrm{a}$ and $\mathrm{b}$ refer to the sample used during the static tensile test. On the other hand, Figures $7 \mathrm{c}$ and $\mathrm{d}$ show the sample fracture obtained as a result of a fatigue crack. In turn, Figure 8 shows the breakthrough structure of the DMLS sample. Figures $8 \mathrm{a}$ and $\mathrm{b}$ show the photos of the fractures of the samples after the tests under static loads. Figures $8 \mathrm{c}$ and $\mathrm{d}$ show the photos of the fractures of the samples after fatigue tests.

Electron microscope photos show the difference in the cracking of DB and DMLS samples during the static tensile test and fatigue tests. The analysis of the photos showed that the DMLS printed samples were characterized by construction defects, i.e. porosity and voids resulting from the process of manufacturing the element with additive technology. Fatigue cracks were caused mainly by surface defects resulting from the high roughness of the surface of samples made with the DMLS technology.

\section{The results analysis}

The tests of samples made of a drawn bar (DB sample) and samples made with the additive DMLS method (DMLS sample) under static load conditions allowed to determine the strength parameters. The determined value of the yield point $S_{\mathrm{y} 0.2}$ and material strength $S_{u}$ for DMLS samples are higher by about $11 \%$ than the results for DB samples. Young's modulus $\mathrm{E}$ values for DB samples and DMLS samples are similar. The values of the E parameter indicate that the technology of making samples from the Ti6Al4V titanium alloy does not affect its value. This type of property can be used in the implementation of numerical calculations using the finite element method. Calculations of structural elements made with the additive DMLS method can be performed using the properties of the titanium alloy produced by the traditional method.

Comparing the results obtained during the own research, it can be stated that they are similar to those contained in the literature data. This proves the possibility of obtaining structural elements made with the additive technology of Ti6Al4V alloy with repeatable mechanical properties and similar structures, despite the difference in the initial process settings.

The tests carried out under the conditions of programmed loads with deformation control allowed to determine plastic deformations, stress amplitude and energy depending on the number of block cycles. 
Fig. 9 shows the cyclic deformation diagrams obtained on the basis of the tests programmed for the DMLS sample (Fig. 9a) and the PC sample (Fig. 9b). The parameters of the charts below are summarized in Table 3 .

Table 3. Parameters describing the diagrams of the cyclic deformation of the Ti6Al4V material.

\begin{tabular}{|c|c|c|}
\hline \multirow{2}{*}{ Sample name } & \multicolumn{2}{|c|}{ Parameter } \\
\cline { 2 - 3 } & $\mathrm{K}$ & $\mathrm{n}^{\prime}$ \\
\cline { 2 - 3 } & $\mathrm{MPa}$ & - \\
\hline DMLS Specimen & 2082.8 & 0.1319 \\
\hline DB Specimen & 959.9 & 0.0412 \\
\hline
\end{tabular}

The diagrams shows that the Ti6Al4V material produced by the DMLS additive method is characterized by higher deformation parameters, i.e. the cyclic strengthening factor $\mathrm{k}$ 'and the cyclic strengthening exponent n'. It can be seen that for the same strain values, the DMLS sample achieves higher stress amplitude values. With the increase of the deformation value, the difference in the achieved stress amplitude values increases.

a)

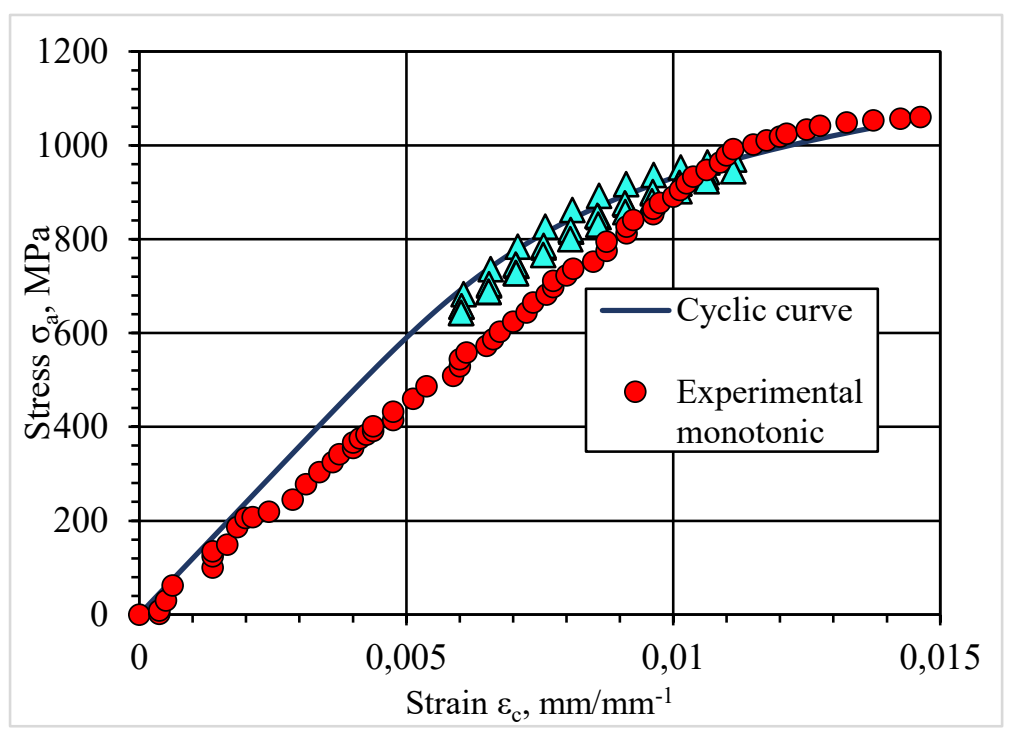

b) 


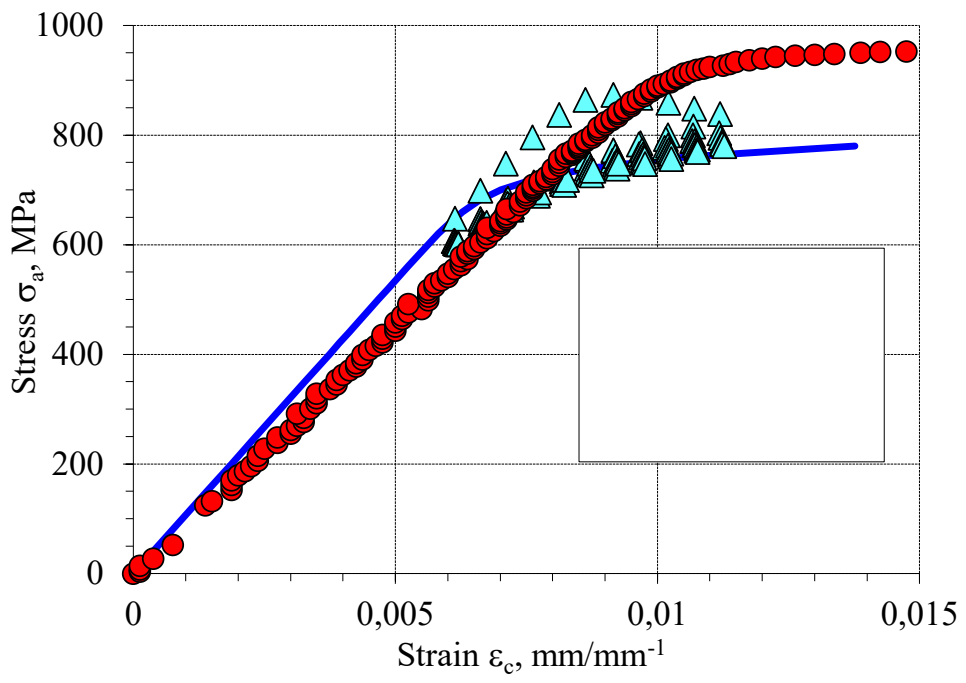

Fig.9. Cyclic strain plots: a) for DMLS sample, b) for DB sample.

\section{Conclusion}

Significant differences were observed in the behavior of Ti6Al4V material in the form of samples made of a drawn bar and in the production of additive DMLS. The differences in the obtained results may be influenced by the production method of the Ti6Al4V material, and thus also by the structure of this material. Thanks to the use of SEM, it was possible to compare the structures of both types of samples. In the case of the DMLS sample, microscopic photos revealed a number of defects, including porosity, unmelted metal powder, metallic inclusions which significantly lowered the fatigue life. The roughness of the surface of the samples may also affect the worse results of fatigue tests in comparison to the DB sample, which, however, was not included in the above work.

\section{References}

1. D. Agius, K. I. Kourousis, C. Wallbrink, Metals, 8, 75 (2018)

2. D. Buchbinder, H. Schleifenbaum, S. Heidrich, W. Meiners, J. Bültmann, Physics Procedia, 12, 1 (2011)

3. T. Duda, L. V. Raghavan, IFAC-Papers On Line, 49, 29 (2016)

4. S. L. N. Ford, Journal of International Commerce, Economics and Policy, 6, 40 (2014)

5. L. E. Murr, Metallography, Microstructure, and Analysis, 7 (2018)

6. L. E. Murr, E. Martinez, K. N. Amato, S. M. Gaytan, J. Hernandez, D. A. Ramirez, et al., Journal of Materials Research and Technology, 1, 1 (2012)

7. S. Hassanajili, A. Karami-Pour, A. Oryan, T. Talaei-Khozani, Materials Science and Engineering: C Materials for Biological Applications, 104 (2018)

8. M. Dallago, V. Fontanari, E. Torresani, M. Leoni, C. Pederzolli, C. Potrich, M. Benedetti, Journal of the Mechanical Behavior of Biomedical Materials, 78 (2018)

9. V. Raja, S. Zhang, J. Garside, C. Ryall, D. Wimpenny, International Journal of Advanced Manufacturing Technology, 27 (2006) 
10. S. Liu, Y. Shin, Materials \& Design, 164 (2018)

11. PN-74/H-04327:1974 Badanie metali na zmęczenie - Próba osiowego rozciągania ściskania przy stałym cyklu obciążeń zewnętrznych.

12. PN-EN ISO 6892-1:2020 Metale -- Próba rozciągania -- Część 1: Metoda badania w temperaturze pokojowej. 